\title{
DNA Purification by Solid Phase Extraction (SPE) Methods
}

\section{Katı Faz Ayırma Yöntemiyle DNA Saflaştırılması}

\author{
Review Article
}

\section{Aykut Arif Topçu1*, Süleyman Aşır², Deniz Türkmen ${ }^{3}$}

${ }^{1}$ Aksaray University, Faculty of Art and Science, Chemistry Department, Aksaray Turkey. ${ }^{2}$ Near East University, Faculty of Engineering, Nicosia, N. Cyprus Mersin 10, Turkey.

${ }^{3}$ Hacettepe University, Faculty of Science, Chemistry Deparment, Beytepe, Ankara, Turkey.

\section{A B S TR AC T}

D NA isolation/purification is a widely used procedure for molecular biology, medical studies, gene therapy and especially PCR studies which needs high quality or extremely pure nucleic acid samples. Nucleic acid separation was mainly achieved by two methods; solvent extraction and solid phase extraction (SPE) methods. Although solvent extraction method is the simplest method, there are some drawbacks such as toxicity, more solvent requirement, time-consuming procedure and low specificity. Nowadays, there is a wide use of solid phase matrices to extract DNA from a variety of samples. In this review article; we basically focused on SPE for DNA purification methods.

\section{Key Words}

DNA, DNA separation, DNA purification, SPE.

\section{ÖZET}

NA'nın saflaştırılması veya izole edilmesi moleküler biyoloji, tıbbi çalışmalar ve gen tedavi çalışmaları için önem taşır. Özellikle PCR çalışmaları için yüksek saflıkta DNA molekülüne intiyaç duyulmaktadır. Nükleik asitlerin saflaştırılmasında sırasıyla çözücü özütlemesi ve katı faz özütlemesi olmak üzere iki yöntem kulanılır. Çözücü ekstraksiyonu kolay uygulanabilir olmasına rağmen; toksisite, yüksek oranda çözücü intiyacı, yöntemin uzun zaman alması ve düşük özgüllüğü gibi birtakım kısıtlamalar mecvuttur. Günümüzde çeşitli örneklerden DNA'nın saflaştırılması için katı faz özütlemesi (SPE) yaygın olarak kullanılmaktadır. Bu çalışmada; özellikle DNA'nın saflaştırılması için SPE yönteminin uygulamaları üzerinde durulmuş ve bilimsel çalışmalar özetlenmiştir.

\section{Anahtar Kelimeler}

DNA, DNA ayrılması, DNA saflaştırılması, SPE.

Article History: Received: May 22, 2016; Revised: Jun 19, 2016; Accepted: Jul 10, 2016; Available Online: Jul $31,2016$.

DOI: $10.15671 / \mathrm{HJBC} .20164420568$

Correspondence to: A.A. Topçu, Aksaray University, Faculty of Art and Science, Chemistry Department, Aksaray Turkey. 


\section{INTRODUCTION}

D NA isolation dated back $17^{\text {th }}$ century whose quality, impurity and isolation strategy are important for purification procedures used in a broad range of application areas including molecular biology, genomics, biotechnology, clinical research and especially obtaining pure and high quality DNA samples are of paramount importance for polymerase chain reaction (PCR) [1-7]. When considered from this point of view, the ability to extract pure DNA efficiently is extremely critical, to ensure needed amounts of genomic and/or plasmid DNA, while removing contaminants that can effect further use of DNA and shorten the shelf-life.

DNA molecules must be extracted from other cellular components before their use in different kind of applications. Cellular components like membranes, organelles and proteins that surround and preserve DNA in the biological environment can inhibit the use of DNA molecules in these applications. For this reason, several DNA extraction methods have been developed to separate cellular components from DNA.

DNA/RNA or nucleic acids lost their solubilities in organic solvents (phenol or chloroform). Because of the solubility differences, solvent extraction method is basically used as nucleic acid isolation. Main drawbacks of the solvent extraction method are contamination, time-consuming procedure, device requirement, low specificity and toxicity of the solvents used [7-10]. Another approach is solid phase extraction (SPE) method; which is based on the interaction between selected analyte in the liquid phase and support material. SPE techniques have been used since 1980 [11]. SPE is not only an economic method but also a high recovery analyte enrichment method whose adsorbents are prepared with different forms such as cryogel, monolith, disc etc. [12-15]. Herein, we summarized traditional nucleic acid purification techniques with many research articles but especially focused on SPE methods.

\section{DNA Separation With Magnetic Particles:}

Magnetic separation (MS) is an alternative technique for separation and purification of selected molecule by using magnetic field (16,
Figure 1). MS is a useful separation method owing to some properties such as; protection of desired molecule towards physical/chemical conditions and the use of advanced devices like centrifuge is not necessary $[16,17]$. Percin et al., prepared poly(hydroxyethyl methacrylate) magnetic nanoparticles in the presence of $\mathrm{Fe}_{3} \mathrm{O}_{4}$ and $\mathrm{N}$-metacryloyl-(L)-histidine as a ligand for plasmid DNA purification from Escheria coli [18]. According to experimental results; total amount of adsorbed and recovery capacities of plasmid DNA were identified $154 \mathrm{mg} / \mathrm{g}$ polymer and 92\% respectively. In another study; Hemoglobin was immobilized on magnetic nanoparticles as a SPE adsorbent for plasmid DNA purification [19]. Before DNA adsorption studies; silica based $\mathrm{Fe}_{3} \mathrm{O}_{4}$ was synthesized and its surface was modified for hemoglobin immobilization. In this study, 68.3\% DNA recovery, $27.86 \mathrm{mg} / \mathrm{g}$ adsorbed DNA capacity were identified and hemoglobin modified magnetic particles were also tested towards commercial purification kit. Rahman and Elaissari, synthesized magnetic particles including thermosensitive properties in the presence of $\mathrm{N}$-isopropylacrylamide (NIPAM) [20]. In this study, researchers pointed out that $\mathrm{pH}$ and temperature effects are important parameters for DNA adsorption. According to experimental data, maxiumum adsorbed DNA was found 8.34 $\mu \mathrm{g} / \mathrm{mg}$ at $\mathrm{pH}$ 4.2. They also pointed out that affinity constans and adsorbed amounts of DNA decreased over $\mathrm{pH} 4.2$.

\section{DNA separation by Microfluidic Systems}

Microfluidic systems (MFS) uses small amount of fluids that are easily operated by channel systems or devices. MFS are important tools for many application areas including biomedical, biochemistry, electronic, Lab-on-Chip devices because of many advantageous such as short analysis time, low cost and low sample volume [21-23]. According to Azimi et al. microchips are not widely used for extracting of nucleic acids from blood samples [24]. Hence, researchers used magnetic based microfluidic system for purification spiked bacterial ( $E$. coli and $B$. subtilis) DNA from human blood and amount of recovery DNA was evaluated with PCR study. In another study, disposable PDMS microchip was designed for multipurpose analysis [25]. Buccal 


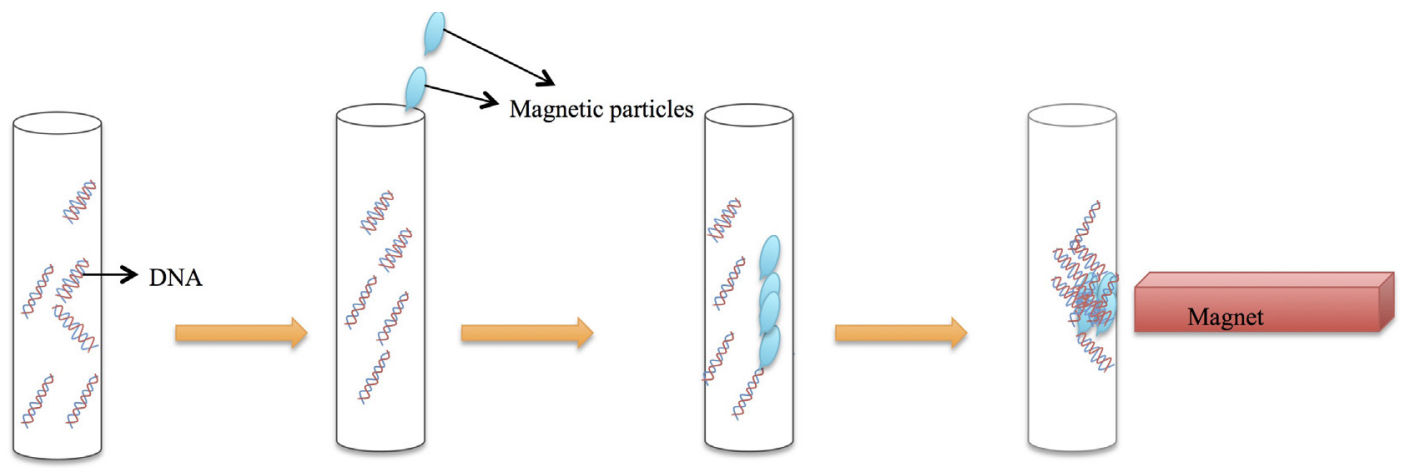

Figure 1. DNA separation with magnetic particles by magnetic field.

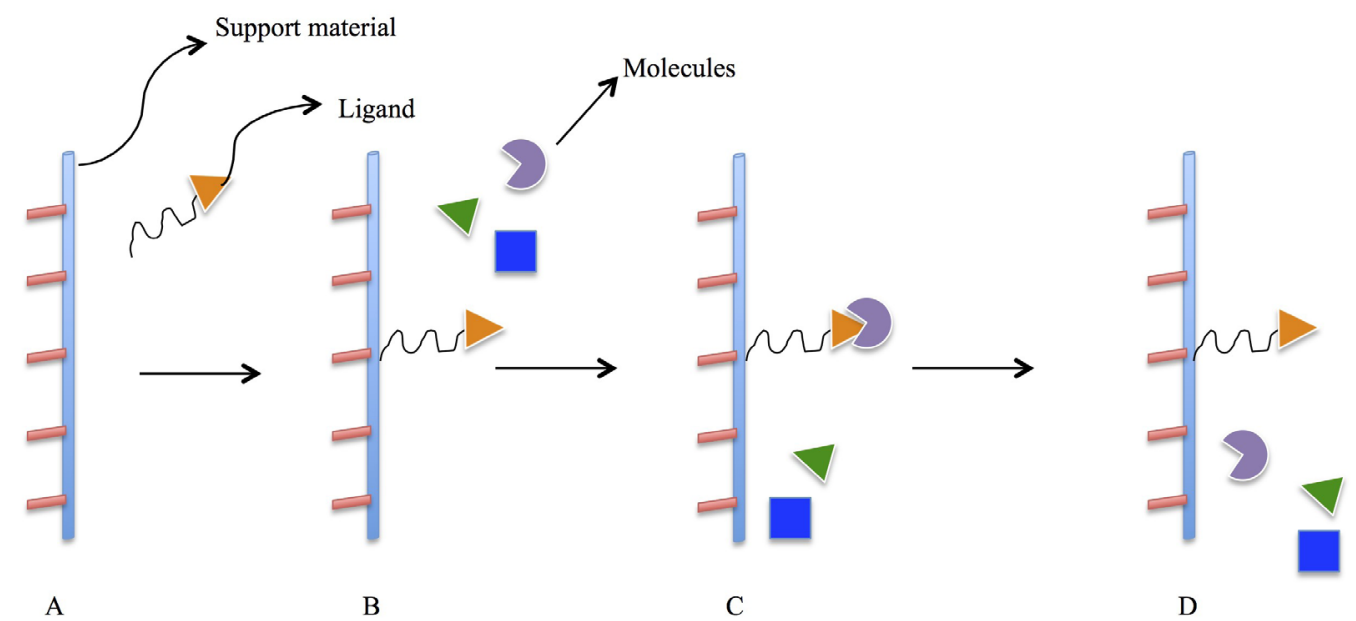

Figure 2. Affinity based separation scheme, (A); activation, (B); ligand immobilization, (C); adsorption and (D); elution.

cell lysis, DNA purification and selected gene PCR analysis were carried out on the same chip, then selected gene amplification result was compared with gel electrophoresis and interestingly all experimental results were completed in a short time nearly 1 hour. Another DNA separation study with microfluidic system based on the microfluidic electrophoresis but this system was combined with end-labeled free-solution electrophoresis (ELFSE) and ion concentration polarization (ICP) system for enrichment of separated DNA molecule in the presence of bipolar electrode system [26]. In this study, Pant and coworkers was used streptavidin as label agent for ELFSE system and modified microfluidic system performance was checked and optimized with various parameters in the presence of modified and unmodified DNA solutions.

DNA Purification by Affinity Chromatography: Affinity chromatography is a useful separation/ purification technique (Figure 2) for many molecules including hormones, proteins and other biologically important molecules. This chromatographic technique uses biospecific interactions of the ligand complementary to the selected molecules $[27,28]$. Typically affinity separation includes three steps (Figure 2); at the first step ligand is covalently immobilized onto support material or matrix for biorecognition, secondly selected molecule is passed through the matrix and finally selected molecule is eluted from 


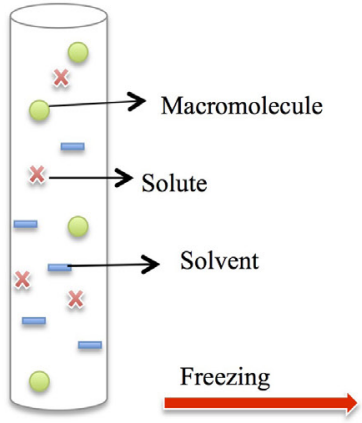

A

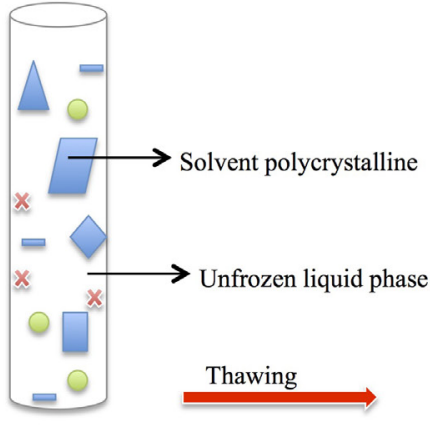

B

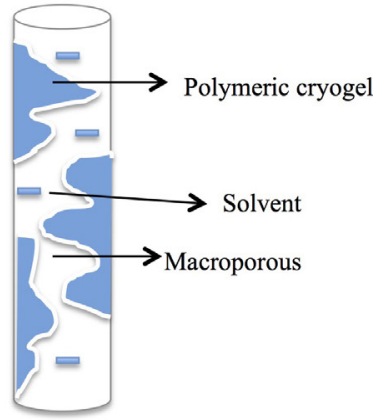

C

Figure 3. Schematic representation of cryogel preparation; (A). before polymerization, (B)., during polymerization, (C). after polymerization.

support material by altering several parameters such as pH, temperature and so on [27].

Nowadays; numerous new affinity support materials including cryogels has been synthesized and developed for separation/purification studies [29]. Cryogels are prepared under semi-frozen conditions and possess several unique properties compared to traditional gels (Figure 3). These include elasticity, macroporous structure, low resistance and low pressure drop during the adsorption studies $[30,31]$.

In a research study, poly(2-hydroxyethyl methacrylate) (PHEMA) based cryogel was prepared as an affinity adsorbent for treatment of systemic lupus erythematosus (SLE) patients [31]. Before removal of SLE patient's DNA (dsDNA) from plasma; PHEMA cryogel was synthesized via free radical polymerization then poly(ethylene imine) (PEI) was attached on PHEMA cryogel. After the attachment of PEI, DNA was immobilized on cryogel. According to experimental results, maximum anti-dsDNA-antibody adsorption was $70 \times 10^{3} \mathrm{lU} / \mathrm{g}$. In this study, PHEMA cryogel usability was also evaluated towards whole blood sample by researchers. Çimen et al., prepared dye-affinity cryogel discs for plasmid DNA (pDNA) purification [29]. For pDNA purification; Cibacron Blue F3GA was covalently immobilized on cryogel discs and pDNA adsorption studies were evaluated with batch system. Maximum adsorbed pDNA was $32.4 \mathrm{mg} / \mathrm{g}$. Çorman et al., prepared an affinity adsorbent cyrogel for the purification of DNA via hydrophobic interactions [32]. Experimental studies were carried on three types of PHEMA based cryogels embedded PHEMA/MATrp beads, PHEMA/MATrp and PHEMA. Researchers tried to increase the adsorbed amounts of DNA via embedded hydrophobic MATrp beads and optimized the affinity adsorbents with various parameters including salt types, temperature, DNA concentration and reusability. According to experimental results, maximum adsorbed DNA was identified as $37.9 \mathrm{mg} / \mathrm{g}$ in the presence of PHEMA/MATrp beads.

\section{DNA Purification by Electrophoresis}

Electrophoresis is an analytical separation method that uses the different migration velocities of different charged molecules and particles under the guidance of an electrical field in the direction of the electrode bearing the opposite charge (Figure 4). DNA electrophoresis with a high separation efficiency is generally used as an analytical method, but may be performed for preparative purposes prior to use of other methods such as DNA amplification or DNA proliferation $[33,34]$. Molecules of DNA are negatively charged because of the phosphate groups in the molecular structure, so they will migrate toward the anode.

In the mid 1930s, the Swedish chemist Arne Tiselius used the idea of separating charged particles by applying an electrical field. Tiselius used moving boundary electrophoresis to resolve serum proteins [35]. Convection was one of the difficulty causing the transport of particles to be faster than electrophoresis. Using a 


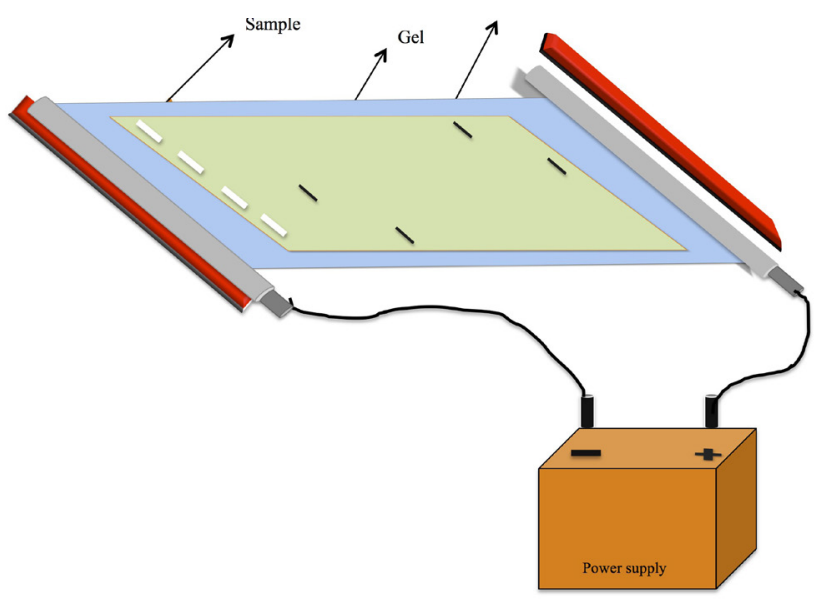

Figure 4. Sample separation with electrophoresis.

supporting matrix solved this problem by acting as an anticonvective medium [36]. Evolved from the methods of protein electrophoresis, the separation of DNA by electrophoresis through a supported matrix was developed by Vin Thorne in the mid 1960s [37]. Thorne was used an agar gel electrophoresis in order to separate superhelical, nicked, and linear forms of DNA. Several supporting media, including agar, agarose, polyacrylamide and composite agarose-acrylamide gels have been used for DNA electrophoresis [37-40]. Together with the anticonvective property of the supporting media, pores of the matrix create a sieving medium for the molecules and separate components of DNA sample into sharp zones.

The electrophoresis of DNA is now the most commonly used method in modern biochemistry and molecular biology for analyses, separation, and purification of DNA fragments. A typical gel electrophoresis method is still a manual process including three steps. These include pouring of gel, applying the voltage for separation, and visualizing the bands. These series of manual tasks is time-consuming, labor intensive and not easily automated. Moreover, most electrophoretic methods are qualitative.

DNA Purification by Capillary Electrophoresis (CE) CE (Figure 5) is a recently developed technique that uses a narrow fused-silica capillary tube (20-200 $\mu \mathrm{m}$ i.d.) to perform high efficiency separation with small amounts of sample. The first separations of DNA by capillary electrophoresis were reported in 1988 by Kasper and Cohen [41, 42]. Main advantages of using this technique include high resolution, shorter analysis time, full automation, ease of data storage, and nanosampling capability. UV detector with a limited sensitivity is commonly used in CE analyses of DNA, but the use of highly sensitive, laserinduced fluorescence (LIF) detector opens up new perspectives for extremely high sensitivity DNA analyses up to yoctomole $\left(10^{-24} \mathrm{~mol}\right)$ range [43]. This approach requires fluorescent derivatives of DNA obtained by binding of fluorogenic dyes.

CE has found extensive use in a broad range of analytical applications which DNA separations are required. These include determining the sequence of bases in DNA and the analyses of samples including DNA and/or its fragments like PCR products [44]. CE as a preparative method is infrequently used, because only small amounts of DNA can be introduced into the system. On the other hand, combination of the CE and PCR amplification methods can circumvent this problem [45]. This approach initally reported by Zhang et al. for ultrasensitive detection of low-abundance proteins that can bind to aptamers. They used the affinity of specific aptamers to target proteins. First, they formed a complex of aptamer (RT 26) and protein (reverse transcriptase of the human immunodeficiency virus), and they used CE to separate proteinaptamer complex. After the collection of proteinaptamer complex, aptamer dissociated from the 


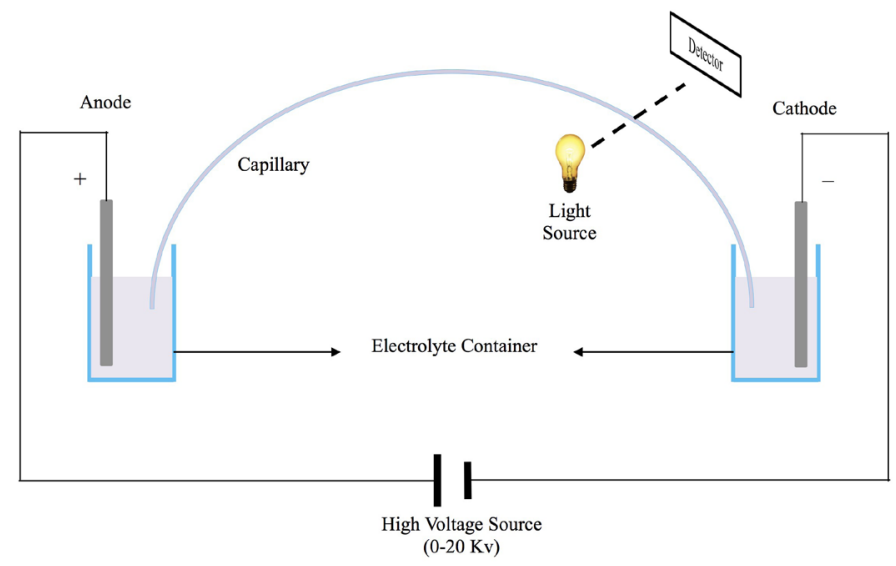

Figure 5. Schematic representation of capillary electrophoresis.

complex and then amplified by PCR.

In another study, Fiore et al. used the advantages of CE for the isolation of the targetbound DNA template and its subsequent amplified quantitation by real-time PCR (RT-PCR) [46] They selected the aptamer of adenosine and first the aptamer was split into two fragments, which are able to assembly in presence of target. They succeeded an ultrafast isolation (60 s) by using CE. By the combination of CE and RT-PCR Fiore et al. showed the determination of adenosine with a LOD of $1 \mu \mathrm{M}$.

\section{DNA Purification with Carbon Nanotubes}

Carbon nanotubes (CNTs) are defined (Figure 6) the roller shape of sheet graphite and synthesized with single or multi walled carbon nanotube forms [47]. CNTs show various and significant properties for instance; which are not only elastic but also steady materials and also posses high surface area, electric and thermal stability but their specific features based on several parameters including atomic organisation, length and diameter of nano tubes and chriality $[47,48]$. CNTs are useful materials for many application areas $[49,50]$ but in this part we only focused on separation studies.

Several adsorption studies have been made by using CNTs. Zheng et al. showed the selective adsorption of DNA molecules to carbon nanotubes for separating single-walled carbon nanotubes (SWNTs) by using the adsorption of
DNA molecules to SWNTs [51]. Li et al. studied the binding of DNA to SWNTs, and reported that DNA destabilization and conformational transition induced by SWNTs are sequence dependent and showed that SWNTs can induce B-A transition for GC-DNA [52]. According to the circular dichroism, competitive binding assay and triplex destabilization results of $\mathrm{Li}$ et al., SWNTs bind to DNA major groove with GC preference.

First adsorption study that offers CNTs to be used as SPE sorbents studied by Shakhmaeva et al., where oxidized multi-layered CNTs were used for separation of supercoiled plasmid DNA [50]. In the experimental study of Shakhmaeva et al. RNA, chromosal DNA and plasmid DNA adsorption behaviors were investigated with oxidized CNTs. For the purification of plasmid DNA especially after isolation from bacteria, contaminating nucleic acids like proteins, chromosomal DNA, RNA and denatured forms of p-DNA can bind on CNTs and removed together with the adsorbent by centrifugation. Using this method the desired molecule, supercoiled $\mathrm{p}$-DNA does not interact with CNTs and remains in solution.

In another study, phenol-stacked CNTs were used for the isolation of genomic DNA from plants [53]. According to results of Zabeti and coworkers, phenol reagent stack on CNTs can effectively remove proteins, polysaccharides and other polyphenol constituents. By this way, fast and effective nucleic acid extraction was achieved by using CNTs. 

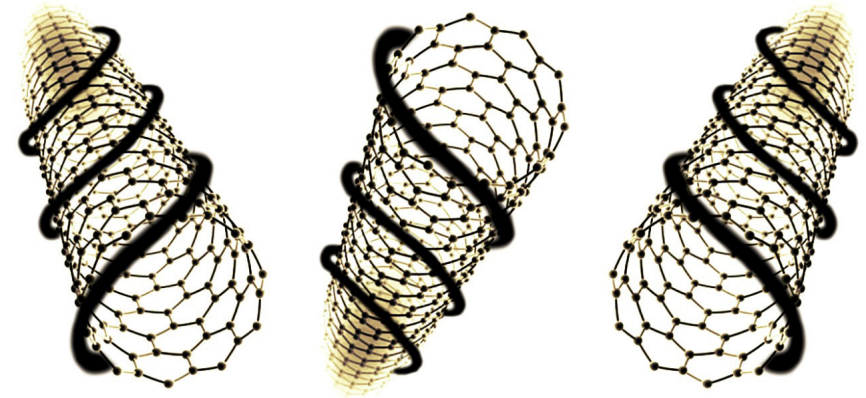

Figure 6. Schematic representation of DNA adsorption to SWNT.

\section{CONCLUSION}

DNA purification is important step for various applications for instance gene therapy, clinical or medical applications, gene vaccines and PCR studies. Herein, we summarized DNA purification with SPE methods because SPE method has many advantageous especially low cost and high recovery efficiency. SPE methods including magnetic particles, affinity chromatography, microfluidic systems, electrophoresis/capillary electrophoresis and carbon nanotubes with various research articles have been explained. The improvement of automation and miniaturization technology has a great effect on the rapid growth on DNA extraction and analyses systems. Development of new techniques for the DNA extraction, which brings various advantages such as, reduced labor and waste, faster processing with higher sensitivity, can be a potential development in the future.

\section{References}

1. D. Cortes-Chosan, R.L. Griffits, Methods for extracting genomic DNA from whole blood samples: current perspectives, J. Biorepository Sci. App. Med, 2 (2014)

2. B. Rittich, A, Spanova, SPE and purification of DNA using magnetic particles, J. Sep. Sci., 36 (2013) 2472.

3. N. Ludwig, Nucleic acid techniques in bacterial systematics and identification, Int. J. Food. Microbiol., 120 (2007) 225.

4. X.Y. Sun, P.Z. Li, B. Ai, Y.B. Wang, Surface modification of MCM-41 and its application in DNA adsorption, Chinese Chem. Lett., 27 (2016) 139.

5. N.M. Fahrenkopf, P.Z. Rice, M. Bergkvist, N.A. Deskins, and N.C. Cady, Immobilization mechanisms of deoxyribonucleic acid (DNA) to hafnium dioxide $\left(\mathrm{HfO}_{2}\right)$ surfaces for biosensing applications, Appl. Mater. Interfaces., 4 (2012) 5360.

6. M.D. Costioli, I. Fisch, F. Flaudy-Garret, F. Hilbrig, R. Freitag, DNA purification by triple-helix affinity precipitation, Biotechnol. Bioeng., 81 (2003) 535.
7. B. Rittich, A. Spanova, SPE and purification of DNA using magnetic particles, J. Sep. Sci., 36 (2013) 2472.

8. J. Sambrook, D.W. Russel, Molecular Cloning, 3rd Ed., Cold Spring Harbor Laboratory Press, NY, USA (2001).

9. M. Wink, An introduction to molecular biotechnology, 2nd Ed, Wiley-VCH Verlag GmbH\&Co, KGaA (2011).

10. M. Deng, C. Jiang, L. Jia, N-Methylimidazolium modified magnetic particles as adsorbents for solid phase extraction of genomic deoxyribonucleic acid from genetically modified soybeans, Anal. Chim. Acta., 771 (2013) 31.

11. C.F. Poole, New trends in solid-phase extraction, Trends. Anal. Chem., 22 (2003) 362.

12. E. Yavuz, Ş. Tokalıoğlu, H. Şahan, Ş. Patat, Nanosized spongelike $\mathrm{Mn}_{3} \mathrm{O}_{4}$ as an adsorbent for preconcentration by vortex assisted solid phase extraction of copper and lead in various food and herb samples, Food Chem., 19 (2016) 463.

13. N. Bereli, K. Köse, D. Türkmen, A. Denizli, A., Glutamic acid containing supermacroporous poly(hydroxyethyl methacrylate) cryogel disks for uranium removal, Mater. Sci. and Eng. C., 32 (2012) 2052.

14. C. Armutcu, N. Bereli, E. Bayram, L. Uzun, R. Say, A. Denizli, Aspartic acid incorporated monolithic columns for affinity glycoprotein purification, Colloids and Surfaces B: Biointerfaces., 114, 67-74, 2014.

15. R. Üzek, L. Uzun, S. Şenel, A. Denizli, Nanospines incorporation into the structure of the hydrophobic cryogels via novel cryogelation method: An alternative sorbent for plasmid DNA purification, Colloid. Surface. B., 102 (2013) 243.

16. C.L. Chiang, C.S. Sung, C.Y. Chen, Application of silica-magnetite nanocomposites to the isolation of ultrapure plasmid DNA from bacterial cells, J. Magn. Magn. Mater., 305 (2006) 483.

17. D. Huska, Automated nucleic acids isolation using paramagnetic microparticles coupled with electrochemical detection, Talanta., 79 (2009) 402.

18. I. Perçin, V. Karakoç, S. Akgöl, E. Aksöz, A. Denizli, Poly(hydroxyethyl methacrylate) based magnetic nanoparticles for plasmid DNA purification from Escherichia coli Iysate, Mater. Sci. Eng. C., 32 (2012) 1133.

19. X.W. Chen, Q.X. Mao, J.W. Liu, J.H. Wang, Isolation/ separationof plasmid DNA using hemoglobin modified magnetic nanocomposites as solid-phase adsorbent, Talanta., 100 (2012) 107.

20. M.M. Rahman, A. Elaissan, Temperature and magnetic dual responsive microparticles for DNA separation, Sep. Purif. Technol., 81 (2011) 286. 
21. G.M. Whitesides, The origins and the future of microfluidics, Nature., 442 (2006) 368.

22. E.K. Sackman, A.L. Fulton, \& D.J. Beebe, The present and future role of microfluidics in biomedical research, Nature., (2104) 507.

23. P. Sajeesh, A.K. Sen, Particle separation and sorting in microfluidic devices: a review, Microfluid. Nanofluid., 17 (2014) 1.

24. A.M. Azimi, et all., A magnetic bead-based DNA extraction and purification microfluidic device, Microfluid. Nanofluid., 11 (2011) 157.

25. W. Cho, J.H. Maeng, S.Y. Hwang, Disposable onchip microfluidic system for buccal cell Iysis, DNA purification, and polymerase chain reaction, Electrophoresis., 34 (2103) 2531.

26. Song, H., Wang, Y., Garson, C. Pant, K., Concurrent DNA preconcentration and separation in bipolar electrode-based microfluidic device, Anal. Method., 7 (2015).

27. A. Denizli, E. Pişkin, Dye-ligand affinity systems, J. Biochem. Biophys. Method., 49 (2001) 391.

28. M. Wilcheck, My life with affinity, Protein Sci., 13 (2004) 3066

29. D. Çimen, F. Yılmaz, I. Perçin, D. Türkmen, A. Denizli, Dye affinity cryogels for plasmid DNA purification, Mater. Sci. and Eng. C., 56 (2015) 318.

30. F.M. Plieva, I.Y. Galaev, B. Mattiason, B., Macroporous gels prepared at subzero temperatures as novel materials for chromatography of particulatecontaining fluids and cell culture applications, J. Sep. Sci., 30 (2007) 1657.

31. E. Özgür, N. Bereli, D. Türkmen, S. Ünal, A. Denizli, PHEMA cryogel for in-vitro removal of anti-dsDNA antibodies from SLE plasma, Mater. Sci. Eng. C., 31 (2011) 915.

32. E. Çorman, N. Bereli, S. Özkara, L. Uzun, A. Denizli, Hydrophobic cryogels for DNA adsorption: Effect of embedding of monosize microbeads into cryogel network on their adsorptive performances., Biomed. Chromatogr., 27 (2013) 1524.

33. J.T. Leonard, M.B. Grace G.S. Buzard, M.J. Mullen, C.B. Barbagallo, Preparation of PCR products for DNA sequencing, Biotechniques., 24 (1998) 314.

34. R. Westermeier, Electrophoresis in Practice, 4th Ed Wiley-VCH Verlag GmbH\&Co, KGaA, Weinheim (2005).

35. Tiselius, A., Electrophoresis of serum globulin. Biochem J, 31 (1937). 313.

36. P. Grabar, C.A. Williams, Method permitting the combined study of the electrophoretic and the immunochemical properties of protein mixtures; application to blood serum, Biochim. Biophys. Acta. 10 (1953) 193.

37. H.V. Thorne, Electrophoretic separation of polyoma virus DNA from host cell DNA, Virology., 29 (1966) 234.

38. C. Aaij, P. Borst, The gel electrophoresis of DNA, Biochim Biophys Acta., 269 (1972) 192.
39. T. Maniatis, A. Jeffrey, H. Van deSande, Chain length determination of small double- and single-stranded DNA molecules by polyacrylamide gel electrophoresis, Biochemistry., 14 (1975) 3787.

40. A.E. Dahlberg, C.W. Dingman, A.C. Peacock, Electrophoretic characterization of bacterial polyribosomes in agarose-acrylamide composite gels J Mol. Biol., 41 (1969) 139.

41. T.J. Kasper, M. Melera, P. Gozel, R.G. Brownlee, Separation and detection of DNA by capillary electrophoresis, J. Chromatogr., 458 (1998) 303.

42. A.S. Cohen, D. Najarian, J.A. Smith, B.L. Karger, Rapid separation of DNA restriction fragments using capillary electrophoresis, J. Chromatogr., 458 (1988) 323.

43. D.Y. Chen, K. Adelhelm, X.L. Cheng, N.J. Dovichi, A simple laser-induced fluorescence detector for sulforhodamine 101 in a capillary electrophoresis sysytem: detection limits of 10 yoctomoles or six molecules, Analyst, 11 (1994) 349.

44. N.J. Dovichi, DNA sequencing by capillary electrophoresis, Electrophoresis, 18 (1997) 2393.

45. H. Zhang, Z. Wang, X. Li, X.C. Le, Ultrasensitive detection of proteins by amplification of affinity aptamers, Angew. Chem. Int. Ed., 45 (2006) 1576.

46. E. Fiore, E. Dausse, H. Dubouchaud, E. Peyrin, C. Ravelet, C., Ultrafast capillary electrophoresis isolation of DNA aptamer for the PCR amplificationbased small analyte sensing, Front. Chem., 3 (2015) 1.

47. E.T. Thostenson, Z. Ren, T.S. Chou, Advanced in the science and technology of carbon nanotubes and their composites: a review, Compos. Sci. Technol., 61 (2001) 1899.

48. P.G. Collins, P. Avouris, Nanotubes for electronics. Sci. Am, 283 (2000) 62.

49. R.H. Baugman, A.A. Zakhidov, W.A, Heer, W.A., Carbon Nanotubes-the Route Toward Applications, Science, 297 (2002) 787.

50. I.I. Shakhmaeva, E.R. Bulatov, O.V. Bondar, D.V. Saifullina, M. Culha, A.A. Rizvanov, T.I. Abdullin, Binding and purification of plasmid DNA using multilayered carbon nanotubes, J. Biotechnol., 152 (2011) 102.

51. M. Zheng, A. Jagota, E.D. Semke, B.A. Diner, R.S. McLean, R.S., Lustig, S.R., Richardson, R.E., Tassi, N.G., DNA-assisted dispersion and separation of carbon nanotubes, Nature Mater, 2 (2003) 338.

52. X. Li, Y. Peng, X. Qu, Carbon nanotubes selective destabilization of duplex and triplex DNA and inducing B-A transition in solution, Nucleic Acids Res., 34 (2006) 3670

53. F. Nazarian-Firouzabadi, A. Ismaili, S.M. Zabeti, Phenol-stacked carbon nanotubes: A new approach to genomic DNA isolation from plants, Mol. Biol. Res. Commun., 3 (2014) 205. 